\title{
Gene expression in sheep carotid arteries: major changes with maturational development
}

\author{
Ravi Goyal' and Lawrence D. Longo ${ }^{1}$
}

BACKGROUND: With development from immature fetus to near-term fetus, newborn, and adult, the cerebral vasculature undergoes a number of fundamental changes. Although the near-term fetus is prepared for a transition from an intra- to extra-uterine existence, this is not necessarily the case with the premature fetus, which is more susceptible to cerebrovascular dysregulation. In this study, we tested the hypothesis that the profound developmental and age-related differences in cerebral blood flow are associated with significant underlying changes in gene expression.

METHODS: With the use of oligonucleotide microarray and pathway analysis, we elucidated significant changes in the transcriptome with development in sheep carotid arteries.

RESULTS: As compared with adult, we demonstrate a U-shaped relationship of gene expression in major cerebrovascular network/pathways during early life, e.g., the level of gene expression in the premature fetus and newborn is considerably greater than that of the near-term fetus. Specifically, cell proliferation, growth, and assembly pathway genes were upregulated during early life. In turn, as compared with adult, mitogen-activated protein kinase-extracellular regulated kinase, actin cytoskeleton, and integrin-signaling pathways were downregulated during early life.

CONCLUSION: In cranial vascular smooth muscle, highly significant changes occur in important cellular and signaling pathways with maturational development.

N eurological impairments such as cerebrovascular accidents and transient ischemic attacks are far too common and increase in prevalence with aging (1). Moreover, in newborn infants hemorrhage into the germinal matrix and periventricular region occurs in 2 to 5 per 1,000 live births and is associated with the development of severe neurological sequelae such as cerebral palsy, convulsive disorders, and other diseases (2). Among very preterm low birth weight (<32 wk gestation; $\leq 1,500 \mathrm{~g}$ ) and particularly among extremely low birth weight ( $<28$ wk gestation; $<1000 \mathrm{~g}$ ) infants, the prevalence of brain damage is particularly high (3). These conditions underscore the importance of a well-regulated cerebral blood flow (CBF) during perinatal development. Moreover, the physiologic and biochemical transitions that occur at the time of birth constitute the single most dramatic series of events in the life of an individual. In these few moments of parturition, the central circulatory pattern must change from one based on placental transfer of respiratory gases to one based on pulmonary ventilation. Systemic vascular resistance increases dramatically, as does arterial blood pressure, while pulmonary vascular resistance and pressure fall. Cardiac (i.e., left-ventricular) output initially increases and then slowly decreases over succeeding days. Despite these dramatic changes in cardiac function and vascular resistance, blood flow to the brain increases only slightly to maintain optimal cerebral oxygenation and metabolism (4). In addition to the cerebral vasculature, per se, carotid arteries (CAs) play a crucial role in maintaining optimal CBF (5). Studies have demonstrated a significant pressure gradient from CAs to cerebral arteries (6), probably to minimize the exposure of high pressure to delicate cerebral arteries, and underscore the importance of CAs in the regulation of CBF. Of note, studies suggest that much of the change in systemic pressure results in dilation/contraction of the large arteries that supply the brain (7). Therefore, failure of CAs to effectively regulate the pressure of the blood reaching delicate cerebral arteries may result in their hemorrhagic rupture. Yet other evidence in premature infants suggests that larger arteries are not able to regulate CBF effectively as in near-term babies (5).

In general, in an infant born at $37 \mathrm{wk}$ gestation or thereafter, the cerebrovascular physiologic transitions usually occur in a well orchestrated fashion. At younger ages $(<37 \mathrm{wk}$, preterm; $<28 \mathrm{wk}$, extremely preterm), however, they may not occur properly, with resultant CBF dysregulation (8). In addition to the changes in cardiovascular dynamics, birth also is associated with a large number of major changes in circulating concentrations of a number of vasoactive hormones and metabolites (9). These include marked increases in norepinephrine and epinephrine, cortisol, the prostaglandins (PGF2 $\alpha$, PGI2, and PGD2), angiotensin II, thyroid-stimulating hormone, and triiodothyronine, as well as increases in bradykinin, free fatty acids, and glycerol. In contrast, the concentrations of circulating adenosine, growth hormone, and PGE2 decrease dramatically (9). Each of these compounds plays an important role in the regulation of vascular reactivity, as well as circulation to the brain and other organs.

Of importance, the cerebral vasculature also undergoes a number of changes with maturational development. During 
the past several decades, the studies of others and our studies have revealed important aspects in the fundamental signaling mechanisms that regulate cerebrovascular contractility with maturational development in the fetus and newborn, as compared with the adult $(10,11)$. Nonetheless, the fundamental, biochemical, and molecular mechanisms responsible for these developmental changes are poorly understood. Some of the most important mechanistic differences include unique features of calcium $\left(\mathrm{Ca}^{2+}\right)$-dependent receptor-second messenger coupling with plasma membrane potassium $\left(\mathrm{K}^{+}\right)$- and $\mathrm{Ca}^{2+}$-channels, and the virtual dependence of the immature organism on extracellular $\mathrm{Ca}^{2+}$ (as opposed to intracellular $\mathrm{Ca}^{2+}$ stores in the adult) for $\mathrm{Ca}^{2+}$-dependent thick (myosin) filament regulation (12). In addition, many elements of the non- $\mathrm{Ca}^{2+}$-dependent pathway of protein kinase $\mathrm{C}$ to specific enzymes such as extracellular regulated kinases (ERK1/2) and their downstream effectors differ in the fetus, as compared with the adult (13). Taken together, these and differences in other enzymes and kinases account for the significantly greater $\mathrm{Ca}^{2+}$ sensitivity of the cerebrovascular contractile mechanisms of the fetus and newborn, as compared with the adult. These studies also emphasize the need to understand the molecular basis of these changes. Unfortunately, and of critical importance, our current understanding of the role of gene expression that underlies cerebrovascular homeostatic mechanisms during maturational development is extremely limited.

To address this vital issue, by use of oligonucleotide microarrays and signal pathway analysis, we tested the hypothesis that the profound age-related differences in the cerebral artery reactivity are associated with significant underlying changes in the gene expression. We examined changes in gene expression in the CAs from four age groups of sheep: premature fetus, near-term fetus, newborn, and adult.

\section{RESULTS}

Our results demonstrate profound changes in ovine carotid artery gene expression profiles with developmental maturation from premature fetus to mature fetus, newborn, and adult. Table 1 enumerates the number of genes with up- and downregulated expression (both $>$ two- and $>$ fourfold-change and $P$ value) in premature fetus, near-term fetus, and newborn lamb as compared with adult sheep. In a striking manner, the changes in CA gene expression profiles from premature fetus and newborn lamb, as compared with adult, differed to a similar extent.

Table 1. Number of genes altered with development

\begin{tabular}{lccc}
\hline & $\begin{array}{c}\text { Premature } \\
\text { fetus }\end{array}$ & $\begin{array}{c}\text { Near-term } \\
\text { fetus }\end{array}$ & Newborn \\
\hline $\begin{array}{l}\text { Genes altered (>twofold; } P<0.05) \\
\text { Upregulated }\end{array}$ & 2,570 & 1,212 & 2,371 \\
$\quad$ Downregulated & 1,907 & 658 & 1,512 \\
Genes altered (>fourfold; $P<0.001)$ & & & \\
$\quad$ Upregulated & 373 & 110 & 304 \\
$\quad$ Downregulated & 255 & 11 & 122 \\
\hline
\end{tabular}

In comparison with adult sheep.
As compared with those of adults, in the near-term fetal CAs fewer genes showed differential regulation. A similar pattern of increased changes in CA gene expression in premature fetus and newborn lamb with far fewer changes in near-term fetus also was observed in several functional (Figure 1) as well as canonical (Figure 2) gene pathways/networks. Striking is the "U" shaped pattern of these gene expression responses. The main canonical pathways altered in early life (premature fetus, near-term fetus, and newborn) as compared with adult were cell-cycle G2/M DNA damage checkpoint regulation, mitotic roles of pololike kinases, and cyclins and cell-cycle regulation pathways. Of relevance, these pathways regulate a number of aspects of cellular growth, proliferation, assembly, DNA replication, cell development, maintenance, and so forth. To validate the relative protein expression as development proceeds, Figure 3 demonstrates that the CA expression of the proteins stathmin 1, filamin A (FLNA), and myosin light chain kinase in premature fetus, near-term fetus, and newborn follows the trend of the microarray analysis.

Tables 2-4 enumerate the top 20 genes with upregulated expression in CAs from premature fetus (Table 2), near-term fetus (Table 3), and newborn lamb (Table 4). Tables 5-7 list the top 10-20 genes downregulated in CAs from premature fetus (Table 5), near-term fetus (Table 6), and newborn lamb (Table 7), as compared with adult sheep. Table 8 lists the major genes involved in cellular growth, proliferation, and assembly pathways that were significantly upregulated during early life. Similarly, Table 9 lists those pathway genes downregulated in early life, as compared with adult. The downregulated genes belonged to the integrin, actin cytoskeleton, and protein kinase C-Rho Kinasemitogen activated protein kinase (MAPK) pathways.

\section{DISCUSSION}

In comparison with those genes in the adult, this study demonstrates the important changes in gene regulation in ovine CAs

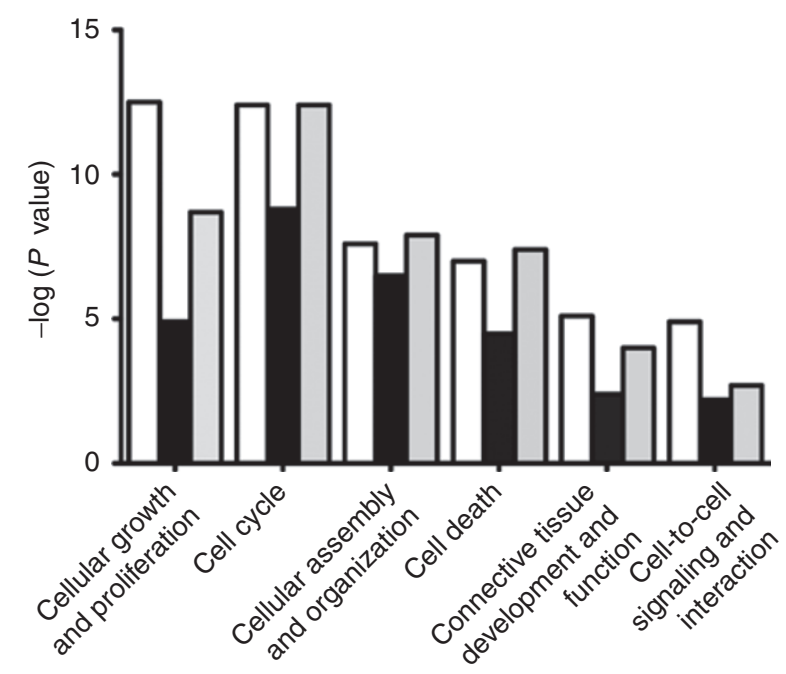

Figure 1. Functional pathways altered with development. Bar graph demonstrates functional pathways altered with development. $n$ was 4 in each experimental group, and all groups were significantly different as compared with adult $(P<0.05)$. White, black, and gray bars show comparison of adult with premature fetus, near-term fetus, and newborn, respectively. 

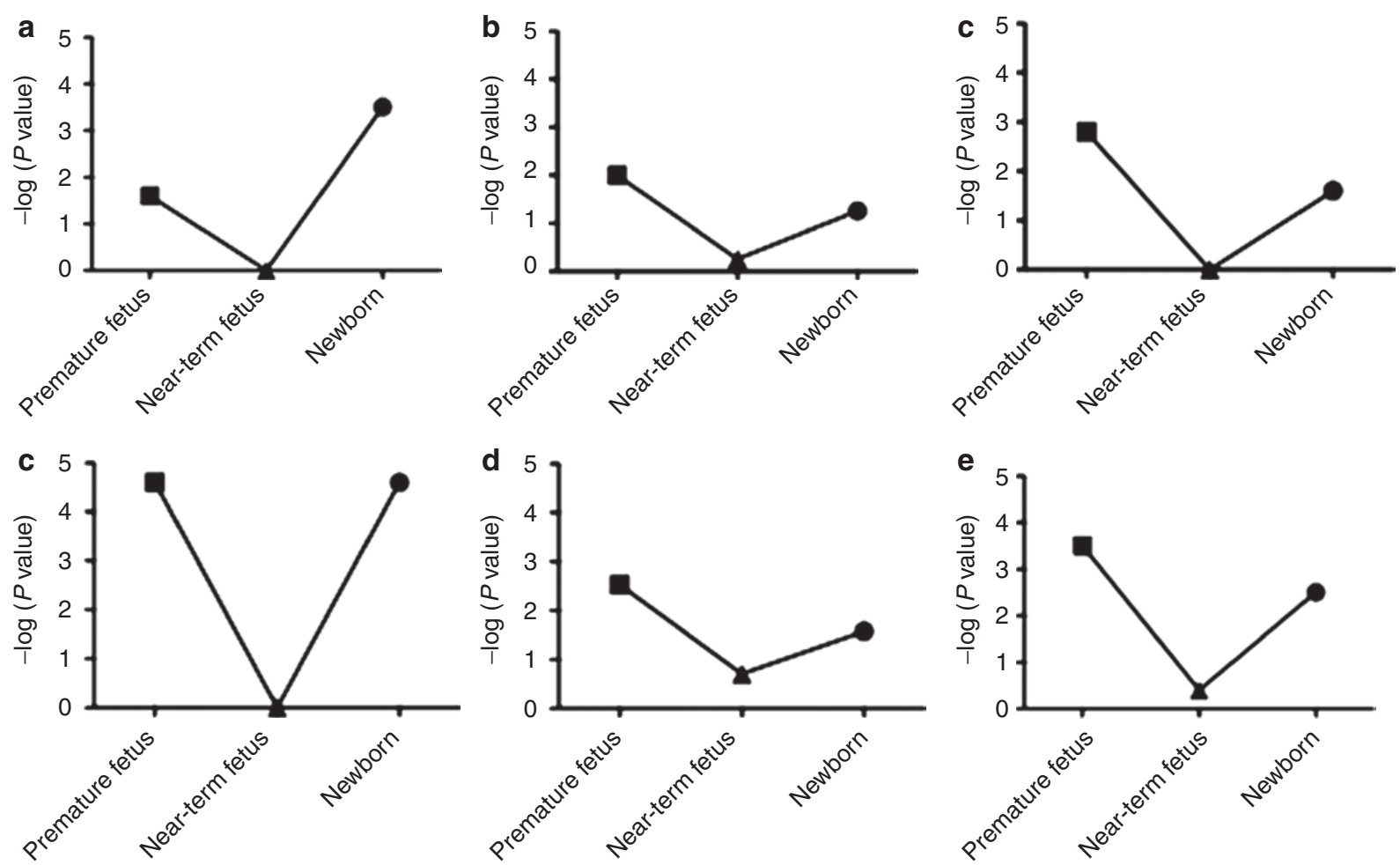

Figure 2. Chief canonical pathways altered with development. Significant differences (-log( $P$ value)) in the (a) extracellular regulated kinases-mitogenactivated kinase, (b) insulin-like growth factor 1, (c) Ras homolog gene family member A, (d) integrin, (e) role of checkpoint proteins, and (f) actin cytoskeleton signaling pathways in the carotid arteries from premature fetus, near-term fetus, and newborn lamb, as compared with those from adult are shown in a line-graph format. $n$ was 4 in each experimental group, and all groups were significantly different as compared with adult $(P<0.05)$.

with developmental maturation from preterm fetus to term fetus and newborn. The changes in gene expression profiles (both up- and downregulation) follow a U-shaped pattern from preterm fetus to near-term fetus and newborn. The deviations of gene expression (either up- or downregulation) are much greater in premature fetus and newborn lamb than in the nearterm fetus. We are not aware of any such report demonstrating that the changes in gene expression profiles are less in a nearterm fetus than those in the premature fetus or newborn. These findings underscore the immense changes in gene expression that occur during the perinatal period, birth, and newborn life and how these differ in unique and unexpected manners. Of critical importance, several parameters associated with cerebral blood flow such as PCO2, hemoglobin grams percent, and heart rate, follow a similar U-shaped pattern during preterm, near-term, and newborn life (14). Therefore, perhaps it should be no surprise that the gene expression follows a somewhat similar pattern. Of critical importance, at present the meaning of these findings in a deep sense is not clear. Furthermore, similar to our finding of a U-shaped curve of gene expression during early life, a number of other significant events, such as complete de-methylation and re-methylation of genome, transcriptional silencing of ovum, and histones acetylation of spermatic DNA still require explanation and understanding, and these findings add to this list.

This study demonstrates that collagen triple helix repeatcontaining protein 1 (Cthrc1) was upregulated $\sim 450$-fold in premature fetus (Table 3); however, its expression decreased 47 -fold in near-term fetus and 35-fold in newborn cerebral arteries. Cthrc1 is a gene product with novel biochemical activities, and its ability to reduce collagen deposition by inhibition of Smad2/3 activation plays a major role in vascular development, repair, and fibrosis (15). Of importance, Cthrc1 also increases cellular migration and reduces collagen deposition (16).

Recently, we reported that from an ultrastructural standpoint cerebral arteries of the premature fetus are significantly more fragile than those of the near-term fetus (17). Cthrc1 upregulation may be responsible for reduced collagen contents and therefore increased fragility, leading to higher propensity of the premature fetus for germinal matrix hemorrhage and other intracerebral bleeds; however, further investigation is needed to examine the role of Cthrcl during fetal life. Similarly, extracellular superoxide dismutase (SOD) expression was significantly downregulated during early life, as compared with adult. Vascular tissue expresses three distinct isoforms of SOD: cytosolic or copper-zinc SOD (CuZnSOD; SOD1), manganese SOD (Mn-SOD) localized in mitochondria (mitochondrial SOD or SOD2), and an extracellular form of CuZn-SOD (EC-SOD; SOD3) (18). Because no selective pharmacological inhibitors of individual SOD isoforms are available, the functional importance of the different SODs has been difficult to define. However, our finding of significantly downregulated expression of specifically 

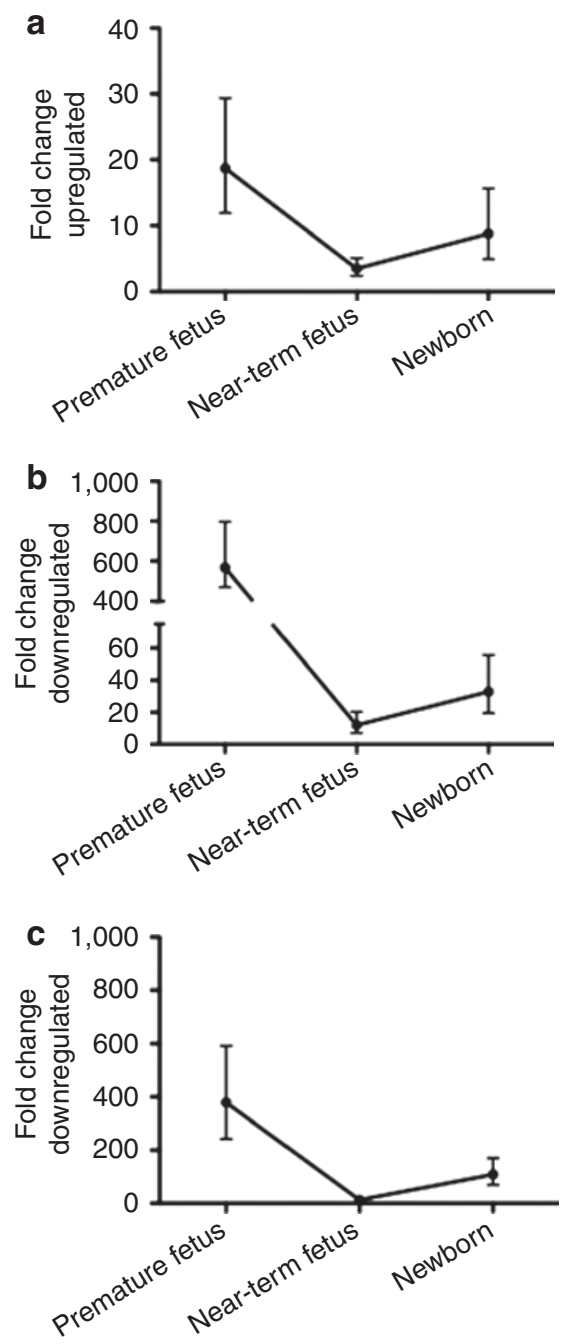

Figure 3. Real-time PCR validation of microarray analysis. Figure demonstrates changes in the expression of (a) staminin 1, (b) filamin A, and (c) myosin light chain kinase mRNA levels in the carotid arteries from premature fetus, near-term fetus, and newborn lamb, as compared with those from adult as determined by quantitative real-time PCR analysis. $n$ was 4 in each experimental group, and all groups were significantly different as compared with adult $(P<0.05)$.

EC-SOD3 suggests a distinct role in early life. SOD plays a crucial role in conversion of superoxide anion $\left(\mathrm{O}_{2}^{-}\right)$to $\mathrm{H}_{2} \mathrm{O}_{2}$; which is further converted to $\mathrm{H}_{2} \mathrm{O}$ by the actions of glutathione peroxidases and peroxiredoxins. Also of importance, in this study we observed that along with reduced expression of SOD3, there was a significantly increased expression of both glutathione peroxidase (GPX8) and peroxiredoxin 4 (PRDX4). Therefore, the system is geared toward reduced production and rapid clearance of $\mathrm{H}_{2} \mathrm{O}_{2}$. At present, the clear rationale of this is not known.

Cell Proliferation, Growth, and Assembly Pathway Gene Expression Is Upregulated During Early Life

To no surprise, many genes involved in cell-cycle regulation, DNA replication, chromosome assembly, and other components of CA cell replication, growth, and assembly demonstrated significantly increased expression. However, of importance, the fold changes of these genes were significantly greater in the premature fetus and newborn than in the nearterm fetus. This emphasizes the complexity of the changes that occur at the several developmental ages. This study also demonstrates that aurora kinase A and B, several cyclins, centromere proteins, and replication factors are significantly upregulated during early life. Overexpression of Aurora A and Aurora $\mathrm{B}$ can lead to genetic instability (gain or loss of whole chromosomes) by the overphosphorylation of normal cell-cycle targets and the aberrant phosphorylation of cytoplasmic targets (19). The resultant chromosomal instability is a common feature of many cancer types (20). A significant over expression of these kinases during fetal life, however, is in contrast to these findings, and suggests that the precise role during early life requires further investigation.

Moreover, ubiquitin-conjugating enzyme e2c (UBE2C) was upregulated almost 260 -fold in the premature fetus and its expression fell to $\sim 66$-fold in the near-term fetus. Nonetheless, this indicates high expression of this gene during early life. Of note, excessive UBE2C is known to disrupt normal chromosome segregation or even lead to mis-separation of the chromosomes (21) and may lead to malignancies (22). However, the significance of such high levels in early life is unknown.

\section{MAPK-ERK Signaling Pathway Gene Expression Is Downregulated in Early Life}

The MAPK pathway is a major signaling cascade involved in cellular growth and development. In this study, several components of the MAPK pathway, including MAPK3, MAP2K2, and MAP kinase interacting serine/threonine kinase 1 and 2, were expressed several fold lower during early life. Of importance, we also observed a significant reduction in the expression of protein kinase $\mathrm{C}$ - delta in fetus and newborn, as compared with adult. Recent studies demonstrate that upstream to the MAPK pathway, protein kinase $\mathrm{C}$ - delta is necessary for the activation of MAPK3 (23). Thus, the findings suggest that several components of the MAPK-ERK pathway are suppressed during early life. Of note, evidence supports the idea that downregulation of this pathway is advantageous for organism survival and well-being. For instance, MAPK3 downregulation has been demonstrated to be beneficial for striatum-dependent long-term memory (24), reduced adiposity, and protection from high-fat diet-induced obesity and insulin resistance (25). Similar results of MAPK-mediated negative regulation of self-renewal cell division have been demonstrated in developing plant cells (26).

On the basis of this study and the above-mentioned reports, reduced expression and down-regulation of MAPK3 would appear to play a critical role in development. In previous reports, we have demonstrated that MAPK plays a significantly reduced role in cerebral arterial contractility during fetal life, compared to that in the adult (27). Nonetheless, the MAPK cascade involvement in negative regulation of vascular growth and development and its role in myofilament $\mathrm{Ca}^{2+}$ sensitivity necessitates further investigation. 
Table 2. Top 20 upregulated genes in premature fetus as compared with adult

\begin{tabular}{|c|c|c|c|}
\hline Symbol & Name & Fold change & $P$ value \\
\hline CTHRC1 & $\begin{array}{l}\text { Collagen triple helix } \\
\text { repeat-containing } 1\end{array}$ & 454.000 & $6.38 \mathrm{E}-05$ \\
\hline$H B B$ & Hemoglobin, $\beta$ & 390.200 & $1.03 \mathrm{E}-05$ \\
\hline UBE2C & $\begin{array}{l}\text { Ubiquitin-conjugating } \\
\text { enzyme E2C }\end{array}$ & 259.300 & $1.89 \mathrm{E}-07$ \\
\hline$C R A B P 1$ & $\begin{array}{l}\text { Cellular retinoic acid } \\
\text { binding protein } 1\end{array}$ & 245.300 & $2.23 \mathrm{E}-04$ \\
\hline KIAA0101 & KIAA0101 & 211.400 & $3.12 \mathrm{E}-08$ \\
\hline COL21A1 & Collagen, type XXI, a1 & 208.100 & $9.59 \mathrm{E}-06$ \\
\hline BIRC5 & $\begin{array}{l}\text { Baculoviral IAP repeat- } \\
\text { containing } 5\end{array}$ & 177.400 & $6.28 \mathrm{E}-06$ \\
\hline MEST & $\begin{array}{l}\text { Mesoderm-specific } \\
\text { transcript homolog }\end{array}$ & 173.800 & $7.54 \mathrm{E}-05$ \\
\hline ACSM1 & $\begin{array}{l}\text { Acyl-CoA synthetase } \\
\text { medium-chain family } \\
\text { member } 1\end{array}$ & 114.900 & $8.84 \mathrm{E}-05$ \\
\hline NCAPG & $\begin{array}{l}\text { Non-SMC condensin I } \\
\text { complex, subunit G }\end{array}$ & 100.500 & $8.00 \mathrm{E}-07$ \\
\hline RBP1 & $\begin{array}{l}\text { Retinol binding protein } 1 \text {, } \\
\text { cellular }\end{array}$ & 81.650 & $5.86 \mathrm{E}-04$ \\
\hline$C P Z$ & Carboxypeptidase Z & 75.910 & $1.29 \mathrm{E}-07$ \\
\hline CKS2 & $\begin{array}{l}\mathrm{CDC} 28 \text { protein kinase } \\
\text { regulatory subunit } 2\end{array}$ & 73.800 & 4.67E-08 \\
\hline STMN1 & Stathmin 1 & 73.070 & $5.69 \mathrm{E}-05$ \\
\hline TF & Transferrin & 65.610 & $3.12 \mathrm{E}-05$ \\
\hline$C D C A 3$ & $\begin{array}{l}\text { Cell division cycle } \\
\text { associated } 3\end{array}$ & 64.230 & $2.42 \mathrm{E}-07$ \\
\hline$A P O A 1$ & Apolipoprotein A-I & 63.910 & $9.65 \mathrm{E}-04$ \\
\hline CENPE & $\begin{array}{l}\text { Centromere protein } \mathrm{E}, \\
312 \mathrm{kDa}\end{array}$ & 61.960 & $1.10 \mathrm{E}-05$ \\
\hline$C D C A 7$ & $\begin{array}{l}\text { Cell division cycle } \\
\text { associated } 7\end{array}$ & 61.590 & $4.44 \mathrm{E}-06$ \\
\hline$A \cup R K B$ & Aurora kinase B & 58.150 & $4.34 \mathrm{E}-07$ \\
\hline
\end{tabular}

Actin Cytoskeleton Pathway Gene Expression Is Downregulated in Early Life

In CAs several important members of the actin cytoskeleton canonical pathways were demonstrated to have reduced expression during early life, as compared with the adult. Of note, FLNA expression was downregulated to a significantly greater extent in premature than in near-term fetal arteries. The reduced expression of FLNA also was significantly more pronounced on real-time PCR analysis, as compared with that of microarray analysis. Several explanations could account for this. For instance, microarray examination is based on the ratio of the densitometric analysis of the signal, whereas in PCR the florescence signal is exponentially weighted to the power of 2 to correct for the doubling with each cycle. This makes the PCR technique much more sensitive as compared with the microarray analysis. Nonetheless, with both techniques, the finding that there is a significantly greater reduction of FLNA in the premature vessels remains
Table 3. Top 20 upregulated genes in near-term fetus as compared with adult

\begin{tabular}{|c|c|c|c|}
\hline Symbol & Name & Fold change & $P$ value \\
\hline$A L D O A$ & $\begin{array}{l}\text { Aldolase A, } \\
\text { fructose-bisphosphate }\end{array}$ & 67.02 & $2.62 \mathrm{E}-04$ \\
\hline UBE2C & $\begin{array}{l}\text { Ubiquitin-conjugating } \\
\text { enzyme } \mathrm{E} 2 \mathrm{C}\end{array}$ & 66.4 & $7.52 \mathrm{E}-05$ \\
\hline MEG3 & $\begin{array}{l}\text { Maternally expressed } 3 \\
\text { (nonprotein coding) }\end{array}$ & 63.3 & $3.19 \mathrm{E}-06$ \\
\hline$E L N$ & Elastin & 55.59 & $3.90 \mathrm{E}-04$ \\
\hline$C R A B P 1$ & $\begin{array}{l}\text { Cellular retinoic acid binding } \\
\text { protein } 1\end{array}$ & 51.01 & $6.76 \mathrm{E}-04$ \\
\hline MEST & $\begin{array}{l}\text { Mesoderm-specific transcript } \\
\text { homolog (mouse) }\end{array}$ & 50.56 & $5.57 \mathrm{E}-05$ \\
\hline APOC2 & Apolipoprotein C-II & 50.26 & $7.34 \mathrm{E}-05$ \\
\hline NCAPG & $\begin{array}{l}\text { Non-SMC condensin I } \\
\text { complex, subunit G }\end{array}$ & 46.93 & $6.68 \mathrm{E}-06$ \\
\hline$H B B$ & Hemoglobin, $\beta$ & 43.91 & $9.42 \mathrm{E}-06$ \\
\hline CENPE & Centromere protein $\mathrm{E}, 312 \mathrm{kDa}$ & 42.58 & $9.18 \mathrm{E}-06$ \\
\hline MFAP2 & $\begin{array}{l}\text { Microfibrillar-associated } \\
\text { protein } 2\end{array}$ & 38.33 & $1.83 \mathrm{E}-04$ \\
\hline$C D C A 3$ & Cell division cycle associated 3 & 37.42 & $1.32 \mathrm{E}-05$ \\
\hline BIRC5 & $\begin{array}{l}\text { Baculoviral IAP } \\
\text { repeat-containing } 5\end{array}$ & 33.53 & $2.65 \mathrm{E}-04$ \\
\hline STAB1 & Stabilin 1 & 33.1 & $6.00 \mathrm{E}-04$ \\
\hline FST & Follistatin & 32.86 & $2.39 \mathrm{E}-04$ \\
\hline FBLN7 & Fibulin 7 & 32.35 & $1.31 E-04$ \\
\hline RNASE1 & $\begin{array}{l}\text { Ribonuclease, RNase A family, } \\
1 \text { (pancreatic) }\end{array}$ & 32.34 & $6.37 \mathrm{E}-04$ \\
\hline CKS2 & $\begin{array}{l}\text { CDC28 protein kinase } \\
\text { regulatory subunit } 2\end{array}$ & 30.33 & $1.50 \mathrm{E}-06$ \\
\hline$A U R K B$ & Aurora kinase B & 30.03 & $3.66 \mathrm{E}-06$ \\
\hline HAPLN1 & $\begin{array}{l}\text { Hyaluronan and proteoglycan } \\
\text { link protein } 1\end{array}$ & 29 & $5.78 \mathrm{E}-05$ \\
\hline
\end{tabular}

the same. Studies have demonstrated that filamin exists in three isoforms, FLNA, filamin B (FLNB), and filamin C (FLNC) (28). Of critical importance, FLNC has been shown to have a restricted expression in skeletal and cardiac muscle (28) and FLNA and FLNB play a crucial role in corticogenesis and brain development (29). However, our study shows significantly greater reduction of FLNA expression in premature CAs, as compared with those of the near-term fetus. Currently, a clear rationale of such a finding is unknown. Nonetheless, this study suggests an important role of FLNA in vascular development. Our results demonstrate further that formin binding protein 1 was reduced significantly during early life. Formin binding protein 1 has been implicated in smooth muscle phenotype switching to a contractile type, and this agrees with our findings (30). Moreover, the actin cytoskeleton signaling cascade has been implicated in a host of functions, including cell motility, surface remodeling, cell shape changes during mitosis, muscle contraction, separation of daughter cells by the contractile ring during cytokinesis, cell-cell, and cell-substrate interactions together with 
Table 4. Top 20 upregulated genes in newborn as compared with adult

\begin{tabular}{|c|c|c|c|}
\hline Symbol & Name & Fold change & $P$ value \\
\hline UBE2C & $\begin{array}{l}\text { Ubiquitin-conjugating enzyme } \\
\text { E2C }\end{array}$ & 146.500 & $3.72 \mathrm{E}-$ \\
\hline ACSM1 & $\begin{array}{l}\text { Acyl-CoA synthetase medium- } \\
\text { chain family member } 1\end{array}$ & 130.000 & $7.60 \mathrm{E}-$ \\
\hline IAA0101 & KIAA0101 & 106.400 & $3.88 \mathrm{E}$ \\
\hline COL21A1 & Collagen, type XXI, a1 & 95.850 & $1.00 \mathrm{E}$ \\
\hline BIRC5 & $\begin{array}{l}\text { Baculoviral IAP } \\
\text { repeat-containing } 5\end{array}$ & 82.050 & $1.81 \mathrm{E}$ \\
\hline NCAPG & $\begin{array}{l}\text { Non-SMC condensin I complex, } \\
\text { subunit G }\end{array}$ & 74.720 & $1.24 \mathrm{E}-$ \\
\hline OGN & Osteoglycin & 73.130 & $9.99 \mathrm{E}-$ \\
\hline HAPLN1 & $\begin{array}{l}\text { Hyaluronan and proteoglycan link } \\
\text { protein } 1\end{array}$ & 72.410 & $8.26 \mathrm{E}$ \\
\hline CKS2 & $\begin{array}{l}\text { CDC28 protein kinase regulatory } \\
\text { subunit } 2\end{array}$ & 57.910 & $3.18 \mathrm{E}-$ \\
\hline DIAPH3 & $\begin{array}{l}\text { Diaphanous homolog } 3 \\
\text { (Drosophila) }\end{array}$ & 46.560 & $9.83 \mathrm{E}-07$ \\
\hline CENPE & Centromere protein $\mathrm{E}, 312 \mathrm{kDa}$ & 42.730 & $3.05 \mathrm{E}-$ \\
\hline CDK1 & Cyclin-dependent kinase 1 & 41.470 & $1.14 \mathrm{E}-05$ \\
\hline GPX8 & $\begin{array}{l}\text { Glutathione peroxidase } 8 \\
\text { (putative) }\end{array}$ & 39.530 & $3.04 \mathrm{E}-$ \\
\hline CCNA2 & Cyclin A2 & 39.310 & $7.80 \mathrm{E}-06$ \\
\hline MEM45A & Transmembrane protein $45 \mathrm{~A}$ & 35.950 & $5.09 \mathrm{E}-$ \\
\hline$A P O C 2$ & Apolipoprotein C-II & 35.900 & $5.67 \mathrm{E}-$ \\
\hline LOX & Lysyl oxidase & 35.710 & $4.65 \mathrm{E}-05$ \\
\hline PRDX4 & Peroxiredoxin 4 & 34.720 & $2.39 \mathrm{E}-05$ \\
\hline ORF4L1 & Mortality factor 4-like 1 & 32.890 & $8.05 \mathrm{E}-0$ \\
\hline MEST & $\begin{array}{l}\text { Mesoderm-specific transcript } \\
\text { homolog (mouse) }\end{array}$ & 28.330 & $1.04 \mathrm{E}-$ \\
\hline
\end{tabular}

adhesion molecules, transmembrane signaling, endocytosis, and secretion (31). Downregulation of this pathway in CAs may suggest that it plays a critical role in the above-mentioned aspects of smooth muscle contractile and/or development pathway and/or phenotype.

\section{Integrin-Signaling Pathway Gene Expression Is Downregulated During Early Life}

Another important signaling pathway altered with development was that of integrin signaling (Table 8). This study demonstrates that major components of the integrin-signaling cascade expression were downregulated in both immature and near-term fetus, as well as newborn CAs. Integrins have been implicated in several fundamental cellular functions such as cellular movement, stabilization, and adhesion (32), as well as internal cellular cytoskeleton organization (33). Evidence also supports the idea that integrins mediate intracellular signaling through janus kinase/signal transducer and activator of transcription and MAPK pathways (34). Not only integrins but also their downstream mediators, such as those involved in MAPK pathway expression, were downregulated. In contrast, caveolin, a scaffolding protein in the integrin signaling cascade, was expressed
Table 5. Top downregulated genes in premature fetus as compared with adult

\begin{tabular}{|c|c|c|c|}
\hline Symbol & Name & Fold change & $P$ value \\
\hline$D E S$ & Desmin & -132.979 & $1.56 \mathrm{E}-04$ \\
\hline MUSTN1 & $\begin{array}{l}\text { Musculoskeletal, } \\
\text { embryonic nuclear } \\
\text { protein } 1\end{array}$ & -102.459 & $9.41 \mathrm{E}-04$ \\
\hline ITGA5 & $\begin{array}{l}\text { Integrin, alpha } 5 \\
\text { (fibronectin receptor, alpha } \\
\text { polypeptide) }\end{array}$ & -39.062 & $7.94 \mathrm{E}-07$ \\
\hline SOD3 & $\begin{array}{l}\text { Superoxide dismutase 3, } \\
\text { extracellular }\end{array}$ & -33.003 & $1.05 \mathrm{E}-04$ \\
\hline PPP1R15A & $\begin{array}{l}\text { Protein phosphatase 1, } \\
\text { regulatory (inhibitor) } \\
\text { subunit 15A }\end{array}$ & -29.326 & $5.16 \mathrm{E}-05$ \\
\hline CSRP1 & $\begin{array}{l}\text { Cysteine- and glycine-rich } \\
\text { protein } 1\end{array}$ & -28.249 & $2.72 \mathrm{E}-08$ \\
\hline PACS1 & $\begin{array}{l}\text { Phosphofurin acidic cluster } \\
\text { sorting protein } 1\end{array}$ & -26.738 & $2.45 \mathrm{E}-07$ \\
\hline FBXO32 & F-box protein 32 & -24.450 & $1.75 \mathrm{E}-04$ \\
\hline$Z Y X$ & Zyxin & -22.936 & $3.75 \mathrm{E}-04$ \\
\hline MID1IP1 & $\begin{array}{l}\text { MID1 interacting protein } 1 \\
\text { (gastrulation-specific G12 } \\
\text { homolog }\end{array}$ & -21.598 & $1.53 \mathrm{E}-07$ \\
\hline ZFP36 & $\begin{array}{l}\text { Zinc finger protein } 36, \mathrm{C} 3 \mathrm{H} \\
\text { type, homolog }\end{array}$ & -18.904 & $7.75 \mathrm{E}-04$ \\
\hline MYL9 & $\begin{array}{l}\text { Myosin light chain 9, } \\
\text { regulatory }\end{array}$ & -18.832 & $1.80 \mathrm{E}-06$ \\
\hline UNC45A & $\begin{array}{l}\text { Unc-45 homolog A } \\
\text { (Caenorhabditis elegans) }\end{array}$ & -17.953 & $6.82 \mathrm{E}-05$ \\
\hline SLC2A4 & $\begin{array}{l}\text { Solute carrier family } \\
2 \text { (facilitated glucose } \\
\text { transporter), member } 4\end{array}$ & -17.422 & $3.47 \mathrm{E}-05$ \\
\hline FLNA & Filamin A, alpha & -16.807 & $4.21 \mathrm{E}-06$ \\
\hline$C E B P B$ & $\begin{array}{l}\text { CCAAT/enhancer binding } \\
\text { protein (C/EBP), beta }\end{array}$ & -16.529 & $3.33 \mathrm{E}-05$ \\
\hline SPHK1 & Sphingosine kinase 1 & -15.974 & $5.99 \mathrm{E}-04$ \\
\hline COPS7A & $\begin{array}{l}\text { COP9 constitutive } \\
\text { photomorphogenic } \\
\text { homolog subunit 7A }\end{array}$ & -15.674 & $1.34 \mathrm{E}-06$ \\
\hline FBXW5 & $\begin{array}{l}\text { F-box and WD repeat } \\
\text { domain-containing } 5\end{array}$ & -15.152 & $5.35 \mathrm{E}-06$ \\
\hline DNAJB5 & $\begin{array}{l}\text { DnaJ (Hsp40) homolog, } \\
\text { subfamily B, member } 5\end{array}$ & -14.006 & $3.06 \mathrm{E}-07$ \\
\hline
\end{tabular}

to a significantly greater extent in premature fetus and newborn, whereas its expression was reduced in near-term fetus. Of note, caveolin links integrin subunits to the tyrosine kinase Fyn, an initiating step in coupling integrins to the Ras-ERK pathway and promoting cell-cycle progression (35). Moreover, it is a negative regulator of the Ras-MAPK cascade (36). As noted, MAPK pathway expression is downregulated in early fetal life, and caveolin, a negative regulator of this pathway expression is upregulated. This suggests an active downregulation of the MAPK cascade and further indicates that MAPK inhibition plays a critical developmental role during early life. 
Table 6 Top downregulated genes in near-term fetus as compared with adult

\begin{tabular}{|c|c|c|c|}
\hline Symbol & Name & Fold change & $P$ value \\
\hline MAPRE2 & $\begin{array}{l}\text { Microtubule-associated } \\
\text { protein, RP/EB family, } \\
\text { member } 2\end{array}$ & -8.475 & $6.97 \mathrm{E}-04$ \\
\hline HSPA1A/HSPA1B & $\begin{array}{l}\text { Heat shock } 70 \mathrm{kDa} \\
\text { protein } 1 \mathrm{~A}\end{array}$ & -6.944 & $7.22 \mathrm{E}-04$ \\
\hline DNAJB5 & $\begin{array}{l}\text { DnaJ (Hsp40) homolog, } \\
\text { subfamily B, member } 5\end{array}$ & -6.711 & $4.54 \mathrm{E}-04$ \\
\hline CAMK2G & $\begin{array}{l}\text { Calcium/calmodulin- } \\
\text { dependent protein } \\
\text { kinase Il gamma }\end{array}$ & -5.747 & $4.65 \mathrm{E}-04$ \\
\hline MYOT & Myotilin & -5.128 & $4.70 \mathrm{E}-04$ \\
\hline PRKCD & Protein kinase C, delta & -4.950 & $8.82 \mathrm{E}-05$ \\
\hline TBC1D1 & $\begin{array}{l}\text { TBC1 (tre-2/USP6, BUB2, } \\
\text { cdc16) domain family, } \\
\text { member } 1\end{array}$ & -4.274 & $7.36 \mathrm{E}-05$ \\
\hline CLIP1 & $\begin{array}{l}\text { CAP-GLY domain- } \\
\text { containing linker } \\
\text { protein } 1\end{array}$ & -4.184 & $3.77 \mathrm{E}-06$ \\
\hline$B Z W 2$ & $\begin{array}{l}\text { Basic leucine zipper and } \\
\text { W2 domains } 2\end{array}$ & -4.167 & $4.04 \mathrm{E}-04$ \\
\hline SQSTM1 & Sequestosome 1 & -4.065 & $8.68 \mathrm{E}-04$ \\
\hline
\end{tabular}

\section{Perspective}

Overall, results of this study demonstrate significant alterations of gene expression with maturation of the cranial vasculature. For the first time, we demonstrate that, as compared with more active gene expression of several signaling pathways in the premature fetus and newborn organism, in the near-term fetus differential gene expression is attenuated significantly. These findings agree with the concept of molecular mechanisms acting in an integrated manner to regulate both phenotypic and mechanical plasticity in vascular smooth muscle cells (37), and may be an important step for the preparation of the fetus for birth. Of importance, our study raises a number of questions regarding the regulation of changes in vascular gene expression and their biological significance in the developing premature fetus, nearterm fetus, and newborn. This study also provides a basis for future studies to explore the importance of changes in the major signal transduction pathways during early vascular development and the function of these changes. Perhaps most important, this study suggests avenues in which to target the developing cerebral vasculature for gene therapy to ameliorate the serious pathophysiologic disruptions that may occur during early life (38).

\section{METHODS}

\section{Experimental Animals and Tissues}

All experimental procedures were performed within the regulations of the Animal Welfare Act, the National Institutes of Health Guide for the Care and Use of Laboratory Animals, "The Guiding Principles in the Care and Use of Animals" approved by the Council of the American Physiological Society, and the Animal Care and Use Committee of Loma Linda University. For these studies, we used CAs from premature (95-gestational-day) fetus, near-term ( 140-gestational-day)
Table 7 Top downregulated genes in newborn lamb as compared with adult

\begin{tabular}{|c|c|c|c|}
\hline Symbol & Name & Fold change & $P$ value \\
\hline PACS1 & $\begin{array}{l}\text { Phosphofurin acidic cluster } \\
\text { sorting protein } 1\end{array}$ & -22.727 & $7.20 \mathrm{E}-07$ \\
\hline SOD3 & $\begin{array}{l}\text { Superoxide dismutase } 3 \text {, } \\
\text { extracellular }\end{array}$ & -20.877 & $1.10 \mathrm{E}-04$ \\
\hline PCIF1 & $\begin{array}{l}\text { PDX1 C-terminal inhibiting } \\
\text { factor } 1\end{array}$ & -15.625 & $1.67 \mathrm{E}-06$ \\
\hline WBP2 & $\begin{array}{l}\text { WW domain-binding } \\
\text { protein } 2\end{array}$ & -15.480 & $1.66 \mathrm{E}-05$ \\
\hline$B C L 6$ & B-cell CLL/lymphoma 6 & -15.038 & $7.42 \mathrm{E}-04$ \\
\hline COPS7A & $\begin{array}{l}\text { COP9 constitutive } \\
\text { photomorphogenic } \\
\text { homolog subunit } 7 \mathrm{~A}\end{array}$ & -14.837 & $1.29 \mathrm{E}-06$ \\
\hline SCAF1 & $\begin{array}{l}\text { SR-related CTD-associated } \\
\text { factor } 1\end{array}$ & -14.184 & $1.14 \mathrm{E}-04$ \\
\hline$S F 3 A 2$ & $\begin{array}{l}\text { Splicing factor 3a, subunit } \\
2,66 \mathrm{kDa}\end{array}$ & -13.441 & $9.22 \mathrm{E}-08$ \\
\hline ITGA5 & $\begin{array}{l}\text { Integrin, alpha } 5 \text { (fibronectin } \\
\text { receptor, alpha polypeptide) }\end{array}$ & -13.405 & $9.38 \mathrm{E}-05$ \\
\hline$Z Y X$ & Zyxin & -13.175 & $1.43 \mathrm{E}-04$ \\
\hline EHD2 & EH-domain containing 2 & -12.315 & $1.24 \mathrm{E}-06$ \\
\hline PDAP1 & PDGFA associated protein 1 & -11.792 & $3.62 \mathrm{E}-06$ \\
\hline RHOG & $\begin{array}{l}\text { Ras homolog gene family, } \\
\text { member G (rho G) }\end{array}$ & -11.507 & $2.06 \mathrm{E}-04$ \\
\hline EFHD2 & $\begin{array}{l}\text { EF-hand domain family, } \\
\text { member D2 }\end{array}$ & -10.941 & $5.35 \mathrm{E}-05$ \\
\hline FAM113B & $\begin{array}{l}\text { Family with sequence } \\
\text { similarity } 113 \text {, member } B\end{array}$ & -10.471 & $1.58 \mathrm{E}-04$ \\
\hline SORBS3 & $\begin{array}{l}\text { Sorbin and SH3 domain- } \\
\text { containing } 3\end{array}$ & -10.020 & $1.68 \mathrm{E}-05$ \\
\hline CALCOCO1 & $\begin{array}{l}\text { Calcium binding and coiled- } \\
\text { coil domain } 1\end{array}$ & -9.434 & $3.89 \mathrm{E}-06$ \\
\hline FBXW5 & $\begin{array}{l}\text { F-box and WD repeat } \\
\text { domain-containing } 5\end{array}$ & -9.434 & $3.22 \mathrm{E}-06$ \\
\hline INO8OB & INO80 complex subunit B & -9.434 & $2.72 \mathrm{E}-05$ \\
\hline MID1IP1 & $\begin{array}{l}\text { MID1 interacting protein } 1 \\
\text { (gastrulation-specific G12 } \\
\text { homolog) }\end{array}$ & -9.434 & $2.01 E-04$ \\
\hline
\end{tabular}

fetus, newborn lamb (1-5 d old), and nonpregnant adult sheep (18-24 mo) obtained from Nebeker Ranch (Lancaster, CA). For each experiment four animals were used; in case of fetal twins only one of the twins was included in the study.

Pregnant and non-pregnant ewes were anesthetized with thiopental sodium $(10 \mathrm{mg} / \mathrm{kg}$, i.v. $)$, and anesthesia was maintained with inhalation of $1 \%$ isoflurane in oxygen throughout surgery. Following delivery of the fetus by hysterotomy, the fetuses and ewes were euthanized with an overdose of the proprietary euthanasia solution, Euthasol (pentobarbital sodium $100 \mathrm{mg} / \mathrm{kg}$ and phenytoin sodium $10 \mathrm{mg} / \mathrm{kg}$; Virbac, Ft. Worth, TX). Studies were performed in isolated CAs cleaned of adipose and connective tissue. To avoid the complications of endothelial-mediated effects, we removed the endothelium by carefully inserting a small wire three times, as previously described (11).

\section{Tissue Collection and Microarray Processing}

In previous studies, we have described this technique in detail (39). Microarray analysis was conducted by using commercial services of 
Table 8. Cellular proliferation, growth, and assembly pathway upregulated in early life

\begin{tabular}{|c|c|c|c|c|c|c|c|}
\hline \multirow[t]{2}{*}{ Symbol } & \multirow[t]{2}{*}{ Entrez gene name } & \multicolumn{2}{|c|}{ Premature fetus vs. adult } & \multicolumn{2}{|c|}{ Near-term fetus vs. adult } & \multicolumn{2}{|c|}{ Newborn vs. adult } \\
\hline & & Fold change & $P$ value & $\begin{array}{c}\text { Fold } \\
\text { change }\end{array}$ & $P$ value & $\begin{array}{c}\text { Fold } \\
\text { change }\end{array}$ & $P$ value \\
\hline ASPM & Asp (abnormal spindle) homolog, microcephaly associated & 37.38 & $9.41 \mathrm{E}-06$ & 19.21 & $2.04 \mathrm{E}-05$ & 16.29 & $5.45 \mathrm{E}-05$ \\
\hline AURKA & Aurora kinase $\mathrm{A}$ & 11.78 & $9.23 \mathrm{E}-05$ & 5.694 & $3.68 \mathrm{E}-04$ & 8.833 & $1.46 \mathrm{E}-04$ \\
\hline AURKB & Aurora kinase B & 58.15 & $4.34 \mathrm{E}-07$ & 30.03 & $3.66 \mathrm{E}-06$ & 27.24 & $1.35 \mathrm{E}-04$ \\
\hline BIRC5 & Baculoviral IAP repeat-containing 5 & 177.4 & $6.28 \mathrm{E}-06$ & 33.53 & $2.65 \mathrm{E}-04$ & 82.05 & $1.81 \mathrm{E}-05$ \\
\hline CCNA2 & Cyclin A2 & 54.41 & $6.46 \mathrm{E}-06$ & 21.72 & $1.93 \mathrm{E}-05$ & 39.31 & $7.80 \mathrm{E}-06$ \\
\hline CCNB2 & Cyclin B2 & 29.65 & $2.08 \mathrm{E}-07$ & 11.42 & $1.67 \mathrm{E}-04$ & 19.98 & $2.42 \mathrm{E}-05$ \\
\hline CDK1 & Cyclin-dependent kinase 1 & 51.19 & $1.61 \mathrm{E}-04$ & 15.16 & $1.97 \mathrm{E}-04$ & 41.47 & $1.14 \mathrm{E}-05$ \\
\hline CDK2 & Cyclin-dependent kinase 2 & 5.852 & $2.12 \mathrm{E}-05$ & 5.064 & $3.75 \mathrm{E}-03$ & 3.454 & $1.71 \mathrm{E}-04$ \\
\hline CDT1 & Chromatin licensing and DNA replication factor 1 & 7.823 & $1.16 \mathrm{E}-04$ & 11.94 & $1.01 \mathrm{E}-02$ & 3.098 & $7.26 \mathrm{E}-03$ \\
\hline CHEK2 & CHK2 checkpoint homolog (Schizosaccharomyces pombe) & 8.841 & $3.65 \mathrm{E}-05$ & 3.24 & $1.27 \mathrm{E}-01$ & 5.385 & $1.81 \mathrm{E}-04$ \\
\hline CENPE & Centromere protein $\mathrm{E}, 312 \mathrm{kDa}$ & 61.96 & $1.10 \mathrm{E}-05$ & 42.58 & $9.18 \mathrm{E}-06$ & 42.73 & $3.05 \mathrm{E}-06$ \\
\hline CENPH & Centromere protein $\mathrm{H}$ & 12.61 & $3.67 \mathrm{E}-06$ & 5.277 & $1.21 \mathrm{E}-04$ & 7.478 & $9.92 \mathrm{E}-06$ \\
\hline CKAP2 & Cytoskeleton associated protein 2 & 30.63 & $1.84 \mathrm{E}-04$ & 19.23 & $1.88 \mathrm{E}-04$ & 19.94 & $8.83 \mathrm{E}-05$ \\
\hline CKS2 & CDC28 protein kinase regulatory subunit 2 & 73.8 & 4.67E-08 & 30.33 & $1.50 \mathrm{E}-06$ & 57.91 & $3.18 \mathrm{E}-06$ \\
\hline DIAPH3 & Diaphanous homolog 3 (Drosophila) & 35.37 & $4.90 \mathrm{E}-06$ & 27.37 & $1.28 \mathrm{E}-06$ & 46.56 & $9.83 \mathrm{E}-07$ \\
\hline ESPL1 & Extra spindle pole bodies homolog 1 (Saccharomyces cerevisiae) & 28.7 & $1.49 \mathrm{E}-04$ & 12.95 & $7.42 \mathrm{E}-05$ & 15.62 & $2.57 \mathrm{E}-05$ \\
\hline GATA6 & GATA binding protein 6 & 33.72 & $8.69 \mathrm{E}-05$ & 8.271 & $2.27 \mathrm{E}-04$ & 16.16 & $1.27 \mathrm{E}-05$ \\
\hline KNTC1 & Kinetochore-associated 1 & 25.58 & $2.16 \mathrm{E}-04$ & 9.572 & 0.00145 & 14.78 & $5.03 \mathrm{E}-04$ \\
\hline MXD3 & MAX dimerization protein 3 & 31.4 & $4.21 \mathrm{E}-06$ & 26.09 & $3.17 \mathrm{E}-06$ & 14.69 & $8.09 E-05$ \\
\hline NCAPG & Non-SMC condensin I complex, subunit G & 100.5 & $8.00 \mathrm{E}-07$ & 46.93 & $6.68 \mathrm{E}-06$ & 74.72 & $1.24 \mathrm{E}-06$ \\
\hline$P R C 1$ & Protein regulator of cytokinesis 1 & 23.2 & $5.61 \mathrm{E}-05$ & 21.77 & $5.18 \mathrm{E}-04$ & 17.77 & $5.21 \mathrm{E}-05$ \\
\hline PCNA & Proliferating cell nuclear antigen & 10.78 & $1.03 \mathrm{E}-04$ & 3.439 & $4.35 \mathrm{E}-04$ & 9.182 & $1.43 \mathrm{E}-05$ \\
\hline RFC1 & Replication factor C (activator 1) 1, $145 \mathrm{kDa}$ & 2.064 & $4.06 \mathrm{E}-03$ & 1.066 & $6.71 \mathrm{E}-01$ & 2.092 & $3.06 \mathrm{E}-03$ \\
\hline RFC3 & Replication factor C (activator 1) 3, $38 \mathrm{kDa}$ & 4.476 & $8.78 \mathrm{E}-04$ & 1.371 & $1.98 \mathrm{E}-01$ & 3.577 & 4.97E-04 \\
\hline RFC4 & Replication factor C (activator 1) 4, $37 \mathrm{kDa}$ & 2.799 & $1.31 \mathrm{E}-02$ & 1.198 & $7.25 \mathrm{E}-01$ & 1.878 & $6.80 \mathrm{E}-02$ \\
\hline RFC5 & Replication factor C (activator 1) 5, 36.5 kDa & 2.486 & $2.22 \mathrm{E}-07$ & 1.348 & $1.68 \mathrm{E}-02$ & 2.065 & $1.55 \mathrm{E}-03$ \\
\hline SKA1 & Spindle and kinetochore associated complex subunit 1 & 26.35 & $3.44 \mathrm{E}-06$ & 12.14 & $6.36 \mathrm{E}-06$ & 17.75 & $7.18 \mathrm{E}-05$ \\
\hline soxg & SRY (sex determining region Y)-box 9 & 8.645 & $2.50 \mathrm{E}-05$ & 9.4 & 0.0017 & 8.419 & $3.40 \mathrm{E}-04$ \\
\hline STMN1 & Stathmin 1 & 73.07 & $5.69 \mathrm{E}-05$ & 20.7 & $9.17 \mathrm{E}-04$ & 27.51 & $2.71 \mathrm{E}-05$ \\
\hline TYMS & Thymidylate synthetase & 15.49 & $6.62 \mathrm{E}-06$ & 11.37 & $4.44 \mathrm{E}-05$ & 7.212 & $5.09 \mathrm{E}-05$ \\
\hline UBE2C & Ubiquitin-conjugating enzyme E2C & 259.3 & $1.89 \mathrm{E}-07$ & 66.4 & $7.52 \mathrm{E}-05$ & 146.5 & $3.72 \mathrm{E}-07$ \\
\hline
\end{tabular}

GenUs Biosystems, Northbrook, IL. Briefly, tissue samples were lysed in Tri-reagent (Ambion, Austin, TX) and total RNA was isolated using phenol/chloroform extraction followed by purification over spin columns (Ambion). The concentration and purity of total RNA was measured by spectrophotometry at optical density 260/280 and the quality of the total RNA sample was assessed using an Agilent Bioanalyzer with the RNA6000 Nano Lab Chip (Agilent Technologies, Santa Clara, CA).

Labeled complementary RNA was prepared by linear amplification of the Poly(A) + RNA population within the total RNA sample. Briefly, $<1 \mu \mathrm{g}$ of total RNA was reverse-transcribed after priming with a DNA oligonucleotide containing the T7 RNA polymerase promoter $5^{\prime}$ to a d(T)24 sequence. After second-strand complementary DNA synthesis and purification of double-stranded complementary DNA, in vitro transcription was performed using T7 RNA polymerase. The quantity and quality of the labeled complementary RNA was assayed by spectrophotometry and the Agilent Bioanalyzer.

One $\mu \mathrm{g}$ of purified complementary RNA was fragmented to uniform size and applied to Agilent Sheep Gene Expression Microarray, $8 \times$ 15K (Design ID 019921, Agilent Technologies) in hybridization buffer.
Arrays were hybridized at $65^{\circ} \mathrm{C}$ for $17 \mathrm{~h}$. in a shaking incubator and washed at $37^{\circ} \mathrm{C}$ for $1 \mathrm{~min}$. Rinsed and dried arrays were scanned with an Agilent G2565 Microarray Scanner (Agilent Technologies) at $5 \mu \mathrm{m}$ resolution. Agilent Feature Extraction software was used to process the scanned images from arrays (gridding and feature intensity extraction) and the data generated for each probe on the array was analyzed with GeneSpring GX v7.3.1 software (Agilent Technologies). Annotations are based on the Agilent eArray annotation file dated January 2010.

\section{Pathway/Network Analysis}

Each gene was annotated manually using NCBI Blast Search, Unigene, Entrez, or other databases. We then analyzed the annotated genes using the Ingenuity Pathway Analysis Program (Ingenuity Systems, Redwood City, CA).

\section{Real-Time PCR Validation}

To validate the results of the microarray analysis, we chose stathmin 1, FLNA, and myosin light chain kinase genes that were highly regulated by development during early life, as compared with adult life, for analysis using real-time PCR. Using the same probe sequences as those on the microarray chip, we designed primers with the use of 
Table 9. Top three downregulated pathways

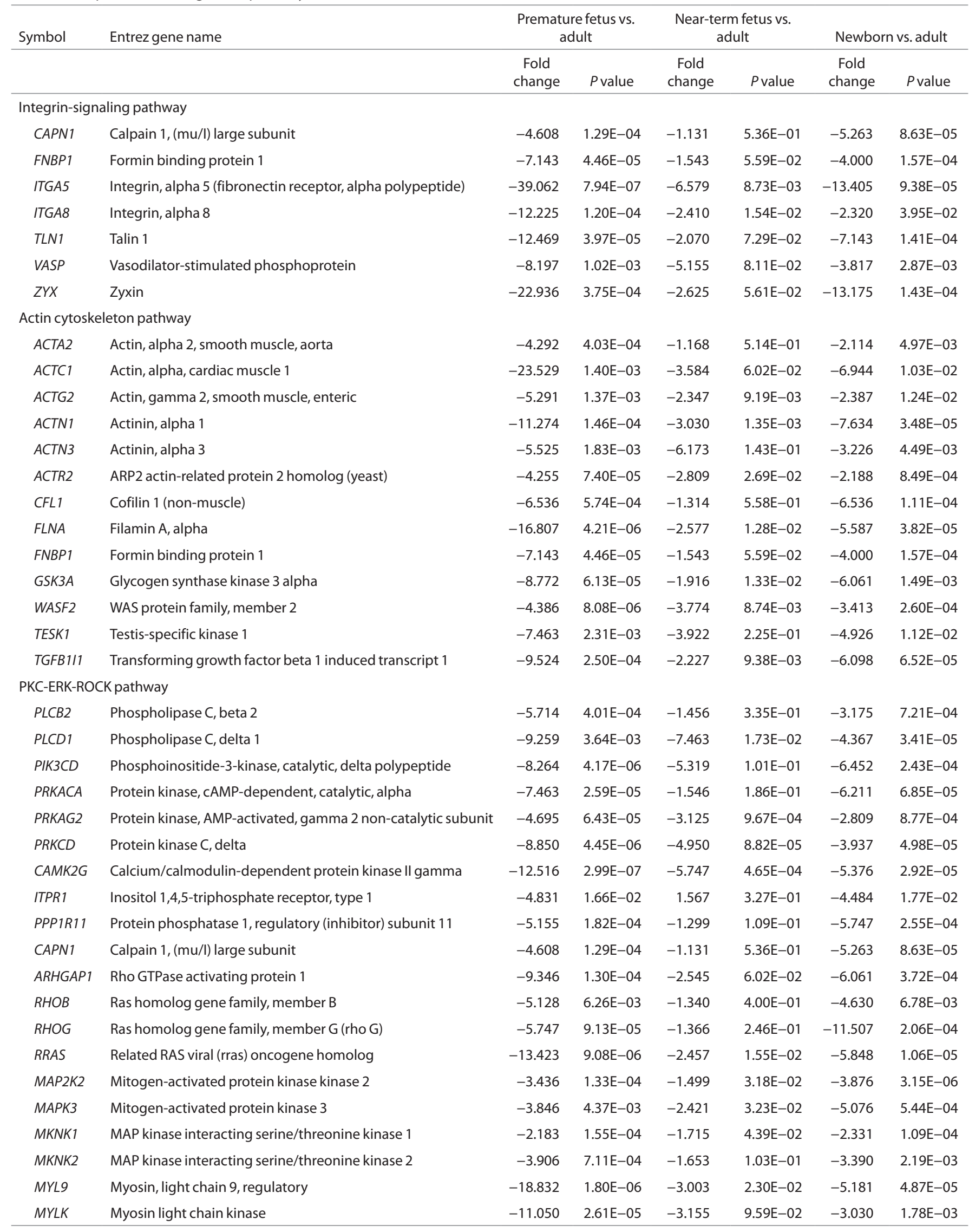


Primer 3 web-based software (http://frodo.wi.mit.edu/primer3/). The primers were synthesized by Integrated DNA technologies (Coralville, CA). Total RNA (1 $\mu \mathrm{g}$ per reaction) was reverse transcribed using Quantitect reverse transcriptase kit (Qiagen, Valencia, CA). Relative expression was normalized to $18 \mathrm{~S}$ RNA and fold changes were calculated using the $\Delta \Delta$ cycle threshold $\left(\mathrm{C}_{\mathrm{T}}\right)$ method (40). Samples were analyzed on the Roche LightCycler 1.5 (Roche, Indianapolis, IN).

\section{Statistics}

To compare individual expression values across arrays, raw intensity data from each gene were normalized to the 75th percentile intensity of each array. Only genes with values greater than background intensity for all samples within each group were used for further analysis. Differentially expressed genes were identified by twofold change and Welch $t$-test $P$ values $<0.05$ between each treatment group and its age-specific normoxic control. Statistical significance in the real-time PCR data was determined by one-way ANOVA and post-hoc Newmans-Keul test.

\section{ACKNOWLEDGMENT}

We acknowledge Nina Chu, Dipali Goyal, Nathanael Matei, and Giovanni A. Longo for their expert technical support. We also acknowledge the staff of GenUs Biosystems for help with the microarray experiments and analysis.

\section{STATEMENT OF FINANCIAL SUPPORT}

The studies were supported by United States Public Health Service grant HD-03807 (to L.D.L.).

\section{REFERENCES}

1. Donnan GA, Fisher M, Macleod M, Davis SM. Stroke. Lancet 2008;371:1612-23.

2. Sheth $\mathrm{RD}$. Trends in incidence and severity of intraventricular hemorrhage. J Child Neurol 1998;13:261-4.

3. Nelson KB. Can we prevent cerebral palsy? N Engl J Med 2003;349:1765-9.

4. Donegan JH, Traystman RJ, Koehler RC, Jones MD Jr, Rogers MC. Cerebrovascular hypoxic and autoregulatory responses during reduced brain metabolism. Am J Physiol 1985;249(2 Pt 2):H421-9.

5. Heistad DD, Marcus ML, Abboud FM. Role of large arteries in regulation of cerebral blood flow in dogs. J Clin Invest 1978;62:761-8.

6. Dieckhoff D, Kanzow E. [On the location of the flow resistance in the cerebral circulation]. Pflugers Arch 1969;310:75-85.

7. Kontos HA, Wei EP, Navari RM, Levasseur JE, Rosenblum WI, Patterson JL Jr. Responses of cerebral arteries and arterioles to acute hypotension and hypertension. Am J Physiol 1978;234:H371-83.

8. Bassan $\mathrm{H}$. Intracranial hemorrhage in the preterm infant: understanding it, preventing it. Clin Perinatol 2009;36:737-62, v.

9. Ward Platt M, Deshpande S. Metabolic adaptation at birth. Semin Fetal Neonatal Med 2005;10:341-50.

10. Wagerle LC, Moliken W, Russo P. Nitric oxide and beta-adrenergic mechanisms modify contractile responses to norepinephrine in ovine fetal and newborn cerebral arteries. Pediatr Res 1995;38:237-42.

11. Goyal R, Mittal A, Chu N, Arthur RA, Zhang L, Longo LD. Maturation and long-term hypoxia-induced acclimatization responses in PKC-mediated signaling pathways in ovine cerebral arterial contractility. Am J Physiol Regul Integr Comp Physiol 2010;299:R1377-86.

12. Goyal R, Creel KD, Chavis E, Smith GD, Longo LD, Wilson SM. Maturation of intracellular calcium homeostasis in sheep pulmonary arterial smooth muscle cells. Am J Physiol Lung Cell Mol Physiol 2008;295:L905-14.

13. Goyal R, Mittal A, Chu N, Zhang L, Longo LD. alpha(1)-Adrenergic receptor subtype function in fetal and adult cerebral arteries. Am J Physiol Heart Circ Physiol 2010;298:H1797-806.

14. Szymonowicz W, Walker AM, Yu VY, Stewart ML, Cannata J, Cussen L. Regional cerebral blood flow after hemorrhagic hypotension in the preterm, near-term, and newborn lamb. Pediatr Res 1990;28:361-6.

15. LeClair $\mathrm{R}$, Lindner $\mathrm{V}$. The role of collagen triple helix repeat containing 1 in injured arteries, collagen expression, and transforming growth factor beta signaling. Trends Cardiovasc Med 2007;17:202-5.

16. Tang L, Dai DL, Su M, Martinka M, Li G, Zhou Y. Aberrant expression of collagen triple helix repeat containing 1 in human solid cancers. Clin Cancer Res 2006;12:3716-22.
17. Goyal R, Henderson DA, Chu N, Longo LD. Ovine middle cerebral artery characterization and quantification of ultrastructure and other features: changes with development. Am J Physiol Regul Integr Comp Physiol 2012;302:R433-45.

18. Faraci FM, Didion SP. Vascular protection: superoxide dismutase isoforms in the vessel wall. Arterioscler Thromb Vasc Biol 2004;24:1367-73.

19. Carvajal RD, Tse A, Schwartz GK. Aurora kinases: new targets for cancer therapy. Clin Cancer Res 2006;12:6869-75.

20. McClellan WJ, Dai Y, Abad-Zapatero C, et al. Discovery of potent and selective thienopyrimidine inhibitors of Aurora kinases. Bioorg Med Chem Lett 2011;21:5620-4.

21. Skibbens RV, Hieter P. Kinetochores and the checkpoint mechanism that monitors for defects in the chromosome segregation machinery. Annu Rev Genet 1998;32:307-37.

22. van Ree JH, Jeganathan KB, Malureanu L, van Deursen JM. Overexpression of the $\mathrm{E} 2$ ubiquitin-conjugating enzyme $\mathrm{UbcH} 10$ causes chromosome missegregation and tumor formation. J Cell Biol 2010;188:83100.

23. Kuriyama M, Taniguchi T, Shirai Y, Sasaki A, Yoshimura A, Saito N. Activation and translocation of PKCdelta is necessary for VEGF-induced ERK activation through KDR in HEK293T cells. Biochem Biophys Res Commun 2004;325:843-51.

24. Mazzucchelli C, Vantaggiato C, Ciamei A, et al. Knockout of ERK1 MAP kinase enhances synaptic plasticity in the striatum and facilitates striatalmediated learning and memory. Neuron 2002;34:807-20.

25. Bost F, Aouadi M, Caron L, et al. The extracellular signal-regulated kinase isoform ERK1 is specifically required for in vitro and in vivo adipogenesis. Diabetes 2005;54:402-11.

26. Lampard GR, Lukowitz W, Ellis BE, Bergmann DC. Novel and expanded roles for MAPK signaling in Arabidopsis stomatal cell fate revealed by cell type-specific manipulations. Plant Cell 2009;21:3506-17.

27. Goyal R, Mittal A, Chu N, Shi L, Zhang L, Longo LD. Maturation and the role of PKC-mediated contractility in ovine cerebral arteries. Am J Physiol Heart Circ Physiol 2009;297:H2242-52.

28. Feng Y, Walsh CA. The many faces of filamin: a versatile molecular scaffold for cell motility and signalling. Nat Cell Biol 2004;6:1034-8.

29. Sheen VL, Feng Y, Graham D, Takafuta T, Shapiro SS, Walsh CA. Filamin A and Filamin B are co-expressed within neurons during periods of neuronal migration and can physically interact. Hum Mol Genet 2002;11: 2845-54.

30. Staus DP, Blaker AL, Medlin MD, Taylor JM, Mack CP. Formin homology domain-containing protein 1 regulates smooth muscle cell phenotype. Arterioscler Thromb Vasc Biol 2011;31:360-7.

31. Schmidt A, Hall MN. Signaling to the actin cytoskeleton. Annu Rev Cell Dev Biol 1998;14:305-38.

32. Campbell ID, Humphries MJ. Integrin structure, activation, and interactions. Cold Spring Harb Perspect Biol 2011;3:1-14.

33. Suen PW, Ilic D, Caveggion E, Berton G, Damsky CH, Lowell CA. Impaired integrin-mediated signal transduction, altered cytoskeletal structure and reduced motility in Hck/Fgr deficient macrophages. J Cell Sci 1999;112 (Pt 22):4067-78.

34. Cabodi S, Di Stefano P, Leal Mdel P, et al. Integrins and signal transduction. Adv Exp Med Biol 2010;674:43-54.

35. Wary KK, Mariotti A, Zurzolo C, Giancotti FG. A requirement for caveolin-1 and associated kinase Fyn in integrin signaling and anchorage-dependent cell growth. Cell 1998;94:625-34.

36. Nonami A, Taketomi T, Kimura A, et al. The Sprouty-related protein, Spred-1, localizes in a lipid raft/caveola and inhibits ERK activation in collaboration with caveolin-1. Genes Cells 2005;10:887-95.

37. Halayko AJ, Solway J. Molecular mechanisms of phenotypic plasticity in smooth muscle cells. J Appl Physiol 2001;90:358-68.

38. Watanabe Y, Heistad DD. Targeting cerebral arteries for gene therapy. Exp Physiol 2005;90:327-31.

39. Goyal R, Yellon SM, Longo LD, Mata-Greenwood E. Placental gene expression in a rat 'model' of placental insufficiency. Placenta 2010;31:568-75.

40. Pfaffl MW. A new mathematical model for relative quantification in realtime RT-PCR. Nucleic Acids Res 2001;29:2003-7. 